\title{
A Study on Chicken Fat as an Alternative Feedstock: Biodiesel Production, Fuel Characterisation, and Diesel Engine Performance Analysis
}

\author{
M. N. Mohiddin, A. A. Saleh", A. N. R. Reddy and S. Hamdan \\ Department of Mechanical and Manufacturing Engineering, Faculty of Engineering, \\ Universiti Malaysia Sarawak, 94300, Kota Samarahan, Sarawak, Malaysia \\ *Email: aasaleh@unimas.my \\ Phone: +6082583299; Fax: +6082583409
}

\begin{abstract}
Biodiesel is one of the promising renewable sources to fulfill the future energy demand of the world. Sustainable feedstock for biodiesel production is one of the major criteria to ensure the process of renewability. Chicken fat is an encouraging feedstock for biodiesel. In this study, waste chicken fat was converted to biodiesel via catalysed transesterification. Optimised process parameters were recorded at 1:4 oil-to-methanol volume ratio and $0.5 \mathrm{wt} \% \mathrm{KOH}$ catalyst concentration with a biodiesel yield of $96 \%$. The FT-IR spectral analysis of chicken fat and chicken fat biodiesel confirmed the conversion of chicken fats into biodiesel. The physico-chemical properties of biodiesel were tested in accordance with ASTM D6751 and EN 14214 biodiesel standards. The specific fuel properties of chicken fat biodiesel that include calorific value, viscosity and acid value were found to be lower than that of petrodiesel. The diesel engine performance tests confirmed that the biodiesel blends performance was similar to petrodiesel. It is noted that while the brake horsepower increased with the increase of biodiesel blending percentage, the engine power output was found to decrease. Specific fuel consumption also increased along with the biodiesel blending percentage.
\end{abstract}

Keywords: Chicken fat; biodiesel; transesterification; engine performance.

\section{INTRODUCTION}

In the near future, world's fossil fuel reserves may be exhausted as their formations take millions of years [1-3]. Some sources even predicted that petroleum oil will be depleted by the year 2045 [4-6]. However, fossil fuels availability may be prolonged by decreasing their overall consumption [7, 8]. The search for technically, economically and environmentally acceptable alternative fuels for diesel engine escalated with the decline of global petroleum reserves and the increase of environmental consciousness especially for transportation sector [9-11].

Biodiesel (mono-alkyl ester) is a biodegradable, renewable and sustainable source of energy. Triglycerides in oil undergoes transesterification process with alcohol to yield biodiesel. The production of biodiesel is possible by utilising oil feedstocks such as waste cooking oil, palm oil, sunflower oil, canola oil, corn oil, fish oil, and chicken fats [12, 13]. Due to various tangible benefits of using biodiesel especially for environmental care and economic development, fats and oil-derived fuels have become attractive alternatives for petroleum-based diesel [14]. Besides, biodiesel is non-toxic and poses no threat to human health $[15,16]$. Biodiesel's major disadvantage is its high commercial cost. Biodiesel costs $50 \%$ more than petroleum diesel [17]. Moreover, the raw material for 
biodiesel production accounts for 70-95 \% of the total cost [18]. The most common feedstocks for biodiesel production are soybean oil, rapeseed oil and palm oil [18-20]. Hence, there is a scientific and economic potential in exploring sustainable and low-cost feedstocks such as animal fats as compared to high-grade vegetable oils [21-24]. Rendered animal fats are sold commercially as animal feed and feedstock for soap production [25]. However, use of animal fats for animal feed is now prohibited due to health concerns, while its disposal through drainage is penalised in some countries [26, 27]. The feedstocks of biodiesel produced from animal fats cost less than other raw materials. Rendered animal fats are inexpensive compared to food-grade vegetable oil and are readily available in the form of wastes in restaurant, food processing industries and fast food shops $[13,28]$. Hence, application of animal fats as biodiesel production feedstock is believed to be favorable as they tend to have low water content and free from fatty acid (FFA) [24, 29, 30]. Biodiesels produced from animal fats are also reported as possessing high cetane number, non-corrosive and clean [31, 32].

This research explores the suitability of chicken fats for producing clean biodiesel. The chicken fat biodiesel (CFB) was produced by catalysed transesterification process using chicken fats. The key reaction parameters include oil-to-methanol volume ratio and catalyst concentration - they were studied in order to optimise the conversion of chicken fat into CFB. The fatty acid composition and chemical structural features of both chicken fat and CFB were analysed by employing chromatographic and Fourier transform infrared (FT-IR) spectro-photographic techniques. The physico-chemical fuel properties of CFB were analysed using an equipment built on EN and ASTM standard methods. The diesel engine performance was studied using blends of CFB and petrodiesel (PD).

\section{METHODOLOGY}

\section{Materials}

The biodiesel feedstock, waste chicken fat was obtained from local food stalls and poultry farms around Kuching and Serian, in the state of Sarawak, Malaysia. The waste chicken fat was heated to $120^{\circ} \mathrm{C}$ for 1 hour to remove any water content in the fat. Extracted oil was filtered through filter paper to remove solid waste. The transesterification reaction was carried out with methanol $\left(\mathrm{CH}_{3} \mathrm{OH}\right)$ and catalysed using potassium hydroxide $(\mathrm{KOH})$ and sodium hydroxide $(\mathrm{NaOH})$.

\section{Chicken Fat Biodiesel Production}

Single-step transesterification was possible for this study as the acid value of the feedstock was less than $2 \mathrm{mg} \mathrm{KOH} / \mathrm{g}$ [11, 33-35]. Methoxide was formed by mixing methanol and catalyst together until they were fully dissolved. Chicken oil was mixed with the methoxide after it had been heated up to $60^{\circ} \mathrm{C}$. The mixture was then stirred at $180 \mathrm{rpm}$ for $60 \mathrm{~min}$. at a reaction temperature of $60^{\circ} \mathrm{C}$. The mixture then settled inside a separating funnel overnight to allow for phase separation by gravity. CFB was formed at the top layer while glycerin by-product was formed at the bottom. CFB was then waterwashed repeatedly until the washing water became neutral. The washed CFB was dried and stored in an airtight container. 


\section{Chicken Fat and Biodiesel Characterisation}

In order to confirm the conversion of chicken fat to biodiesel, chicken fat and CFB samples were directly tested using Fourier transform infrared (FT-IR) spectrophotometer (Shimadzu Iraffinity-1) in a 4000 to $600 \mathrm{~cm}^{-1}$ region with transmittance mode. The fatty acid composition of chicken fat was also analysed through gas chromatography (GC) using Agilent 6890N FID-GC fitted with an Omnistar Q-mass HP-624 Capillary column. Chicken fat's physicochemical properties were analysed and performed as follows: water content (EN ISO 12937), calorific value (ASTM D3338), viscosity (ASTM D445), acid value (ASTM D664), and density (ASTM D4052-91). CFB fuel properties were analysed and performed as follows: calorific value (ASTM D3338), viscosity (ASTM D445), acid value (EN 14104), density (ASTM D1298), cloud point (ASTM D2500), and pour point (ASTM D97) [36, 37].

\section{Engine Performance Test}

CFB was blended with PD in specific blending percentages, i.e. B10 (10\% of CFB blended with $90 \%$ PD by volume), B20, B30, B40, and B50. B0 denotes 100\% PD which serves as a base for comparison. The specifications of the diesel engine used are as shown in Table 1. The speed of engine was varied from $800 \mathrm{rpm}$ to $3600 \mathrm{rpm}$ with $50 \%$ throttle setting for engine performance test.

Table 1. Specifications of diesel engine

\begin{tabular}{ll}
\hline Particulars & Specifications \\
\hline Engine make & ISUZU \\
Model & 4FB1 \\
Type & Water-cooled, four-stroke \\
Combustion & Indirect injection (IDI) and naturally aspirated \\
Number of cylinders & 4 \\
Bore $\times$ stroke & $84 \times 82 \mathrm{~mm}$ \\
Displacement & $1817 \mathrm{cc}$ \\
Compression ratio & $21: 1$ \\
Nominal rated power & $39 \mathrm{~kW} / 5000 \mathrm{rpm}$ \\
Maximum torque speed & $1800-3000 \mathrm{rpm}$ \\
Dimension (L x W x H) & $700 \times 560 \times 635$ (mm) \\
Weight (dry) & $185 \mathrm{~kg}$ \\
Combustion chamber & Swirl Chamber \\
Nozzle type & Throttle \\
Governor type & Mechanical, variable speed, min-max speed \\
Cooling system & Pressurised circulation \\
\hline
\end{tabular}




\section{RESULTS AND DISCUSSION}

\section{Analysis of Chicken Fat Biodiesel Yield}

In biodiesel production both oil-to-methanol ratio and the amount of catalyst play a vital role. Figure 1 shows the effect of oil-to-methanol ratio by volume on the CFB yield. The results show that CFB yield is at its highest at ratio of 1:4 for $\mathrm{KOH}$ and 1:5 for $\mathrm{NaOH}, 94$ and $90 \%$, respectively. The use of methanol exceeding the stoichiometric process was proven to increase the CFB yield. However, excess use of methanol also increases the solubility of glycerin in methanol and causes the process equilibrium to shift backward $[38,39]$. This would result in the decrease of biodiesel yield. [35, 40]. Other factors which can affect the production yield are reaction temperature and pressure, oil type, oil source, and stirring mode $[24,33,41]$.

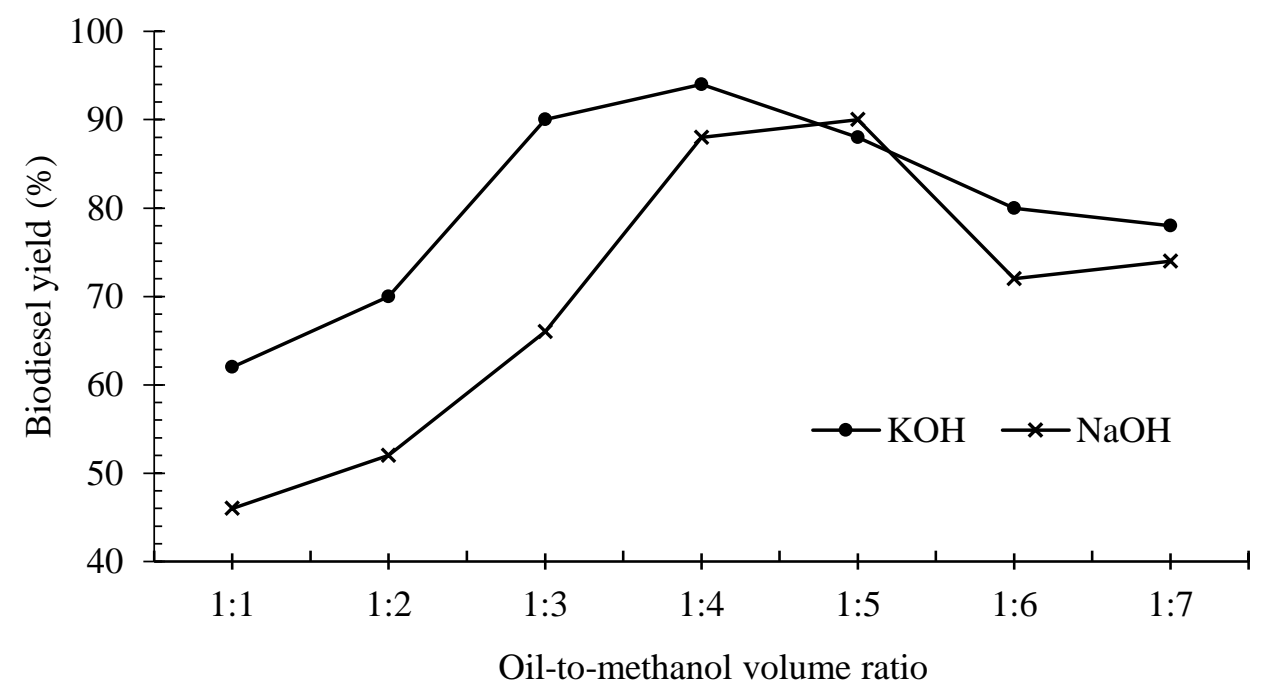

Figure 1. Effect of oil-to-methanol ratio on biodiesel production yield: $0.4 \mathrm{wt} \%, 60{ }^{\circ} \mathrm{C}$.

Figure 2 shows the effect of catalyst concentration on $\mathrm{CFB}$ yield. It can be observed that the CFB yield is higher for $\mathrm{KOH}$ compared to $\mathrm{NaOH}$ at a concentration of less than 0.8 wt. $\%$. A maximum CFB yield of $96 \%$ and $88 \%$ were recorded at 0.5 wt. $\%$ for $\mathrm{KOH}$ and $0.4 \mathrm{wt} . \%$ for $\mathrm{NaOH}$, respectively. On average higher CFB was yielded using $\mathrm{KOH}$ as compared to $\mathrm{NaOH}$. This may be the result of higher solubility of $\mathrm{KOH}$ in organic compound compared to $\mathrm{NaOH}$. Additionally, $\mathrm{KOH}$ is preferable than $\mathrm{NaOH}$ due to the by-product potassium soap which is softer than sodium soap. This implies that separation of finished product is easier for CFB production using $\mathrm{KOH}$ [42]. 


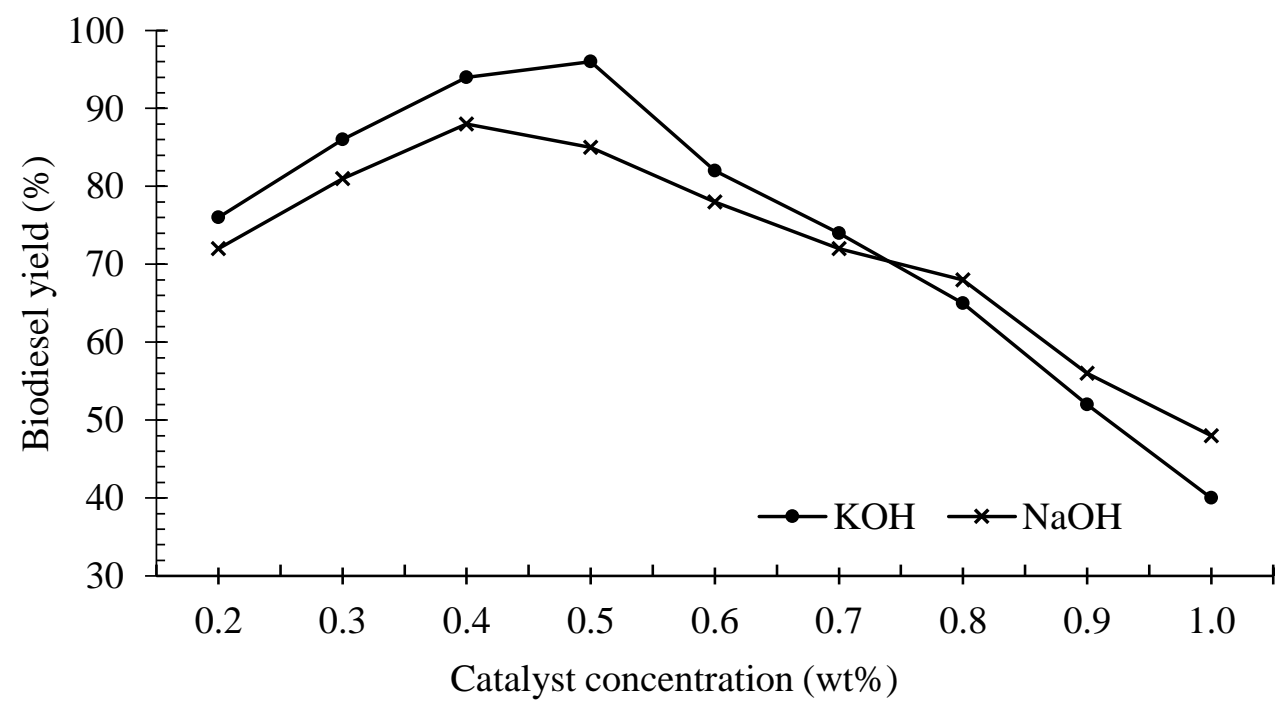

Figure 2. Effect of catalyst concentration on biodiesel yield: oil-to-methanol volume ratio $1: 4,60^{\circ} \mathrm{C}$.

\section{Analysis of Chicken Fat and Biodiesel Fuel Properties}

Figure 3 (a) shows the FT-IR spectrum of chicken fat. A strong peak at $1670-1820 \mathrm{~cm}^{-1}$ shows the presence of carbonyl group $(\mathrm{C}=\mathrm{O})$ which also indicates $\mathrm{C}=\mathrm{O}$ bond stretching [43]. Another peak at $1050-1150 \mathrm{~cm}^{-1}$ indicates $\mathrm{C}-\mathrm{O}$ stretching which is characteristic of carboxylic acids [44]. The absence of strong peaks at $3200-3600 \mathrm{~cm}^{-1}$ which is characteristic of a hydroxyl group $(\mathrm{O}-\mathrm{H})$ shows the absence of mono- and di-glycerides but presence of triglycerides in the chicken fat. Besides, the absence of $\mathrm{O}-\mathrm{H}$ peak also indicates the absence of water and alcohol. The Figure 3 (b) shows the FT-IR spectrum of CFB. The presence of a strong peak at $1670-1820 \mathrm{~cm}^{-1}$ indicates $\mathrm{C}=\mathrm{O}$ stretching. For esters, besides the presence of $\mathrm{C}=\mathrm{O}$ group, another peak at $1050-1150 \mathrm{~cm}^{-1}$ shows $\mathrm{C}-\mathrm{O}$ stretching which is characteristic of an ester [41,45]. The absence of strong peaks at $3200-3600 \mathrm{~cm}^{-1}$ indicates the absence of $\mathrm{O}-\mathrm{H}$ group [44]. This translates into the absence of water and alcohol in the CFB. The fingerprint region $\left(600-1000 \mathrm{~cm}^{-1}\right)$ of both spectra in Figure $3 \mathrm{a}$ and $3 \mathrm{~b}$ are not similar. This shows chicken fat was successfully converted into CFB.

Table 2 shows the fatty acid composition of chicken fat. Saturated compounds (myristic acid, palmitic acid, and stearic acid) produce biodiesel which contains higher cetane number, resists oxidation better and possesses better lubrication properties $[19,37$, 46]. Table 3 shows the physical properties of chicken fat, CFB and standard PD. Chicken fat shows an acceptable amount of water and acid value in which no pretreatment is required for the transesterification to take place [33, 34]. The calorific value of CFB at $43.78 \mathrm{MJ} / \mathrm{kg}$ is $4.3 \%$ lower than PD which is $45.766 \mathrm{MJ} / \mathrm{kg}$. This shows the energy content in CFB is lower than in PD [47, 48]. However, the low calorific value of CFB is a result of its higher oxygen content [49]. Higher oxygen content can be translated into more efficient fuel combustion and less carbon monoxide emission $[33,50]$. The viscosity of CFB at $4.24 \mathrm{~mm} 2 / \mathrm{s}$ is $5.8 \%$ lower than PD which is $4.5 \mathrm{~mm} 2 / \mathrm{s}$. This shows CFB has higher fuel lubricity and better spray characteristics than PD [17, 51]. The acid value of $\mathrm{CFB}$ at $0.15 \mathrm{mg} \mathrm{KOH} / \mathrm{g}$ oil is way below PD standard which is less than $0.8 \mathrm{mg} \mathrm{KOH} / \mathrm{g}$ oil. 


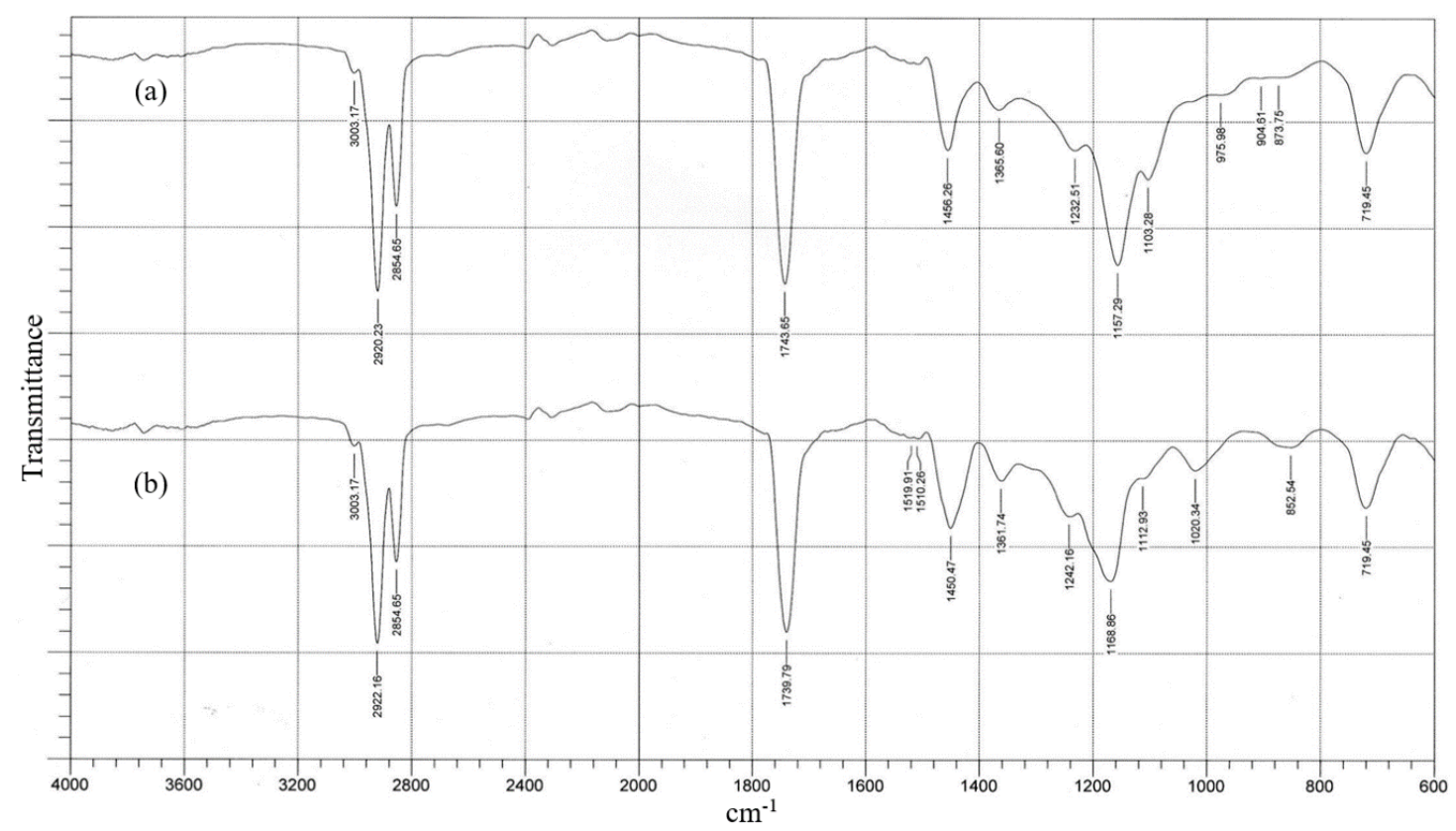

Figure 3. Infrared spectra of (a) chicken fat and (b) chicken fat biodiesel.

Table 2. Fatty acid composition of chicken fat.

\begin{tabular}{lc}
\hline Species & Fatty acid content (\% mass) \\
\hline Myristic (14:0) & 1 \\
Palmitic (16:0) & 22 \\
Stearic (18:0) & 6 \\
Palmitoleic (16:1) & 6 \\
Oleic (18:1) & 37 \\
Linoleic (18:2) & 20 \\
Linolenic (18:3) & 1 \\
Gadoleic (20:1) & 1 \\
Others & 6 \\
\hline
\end{tabular}

Table 3. Comparison of physical properties of chicken fat, chicken fat biodiesel, and petrodiesel.

\begin{tabular}{lccc}
\hline Properties & Chicken fat & $\begin{array}{c}\text { Chicken fat } \\
\text { biodiesel }\end{array}$ & Petrodiesel \\
\hline Water content $(\%$ mass) & 0.7 & - & - \\
Calorific value $(\mathrm{MJ} / \mathrm{kg})$ & 39.398 & 43.780 & 45.766 \\
Viscosity at $40{ }^{\circ} \mathrm{C}\left(\mathrm{mm}^{2} / \mathrm{s}\right)$ & 38.10 & 4.24 & 4.50 \\
Acid value $(\mathrm{mg} \mathrm{KOH} / \mathrm{g})$ & 1.72 & 0.15 & $<0.8$ \\
Density at $15^{\circ} \mathrm{C}\left(\mathrm{kg} / \mathrm{m}^{3}\right)$ & 926 & 874 & 832 \\
Cloud point $\left({ }^{\circ} \mathrm{C}\right)$ & - & 13 & -7 \\
Pour point $\left({ }^{\circ} \mathrm{C}\right)$ & - & 7 & -40 \\
\hline
\end{tabular}




\section{Analysis of Diesel Engine Performance}

Brake horsepower is the amount of power generated by a motor without taking into consideration any auxiliary component which may slow down the actual speed of the motor. Figure 4 shows the brake horsepower of various CFB and PD fuel blends over engine speeds 800-3600 rpm. The brake horsepower generated from the diesel engine increases with the increase in percentage of CFB in the fuel blends. The addition of lube oil in CFB blend helped with fuel combustion. This translates in better fuel spray characteristics and higher brake horsepower [13]. The brake horsepower peaks at 1600 rpm for all diesel and CFB blends except for B40 which peaks at $2000 \mathrm{rpm}$. The marginal variation of $0.73 \mathrm{~kW}$ brake horsepower of B40 fuel, at $2000 \mathrm{rpm}$ as compared to 1600 rpm refers to the difference in CFB fuel characteristics and engine operating conditions [46]. At $1600 \mathrm{rpm}, \mathrm{B} 10, \mathrm{~B} 20, \mathrm{~B} 30$, and B50 produced 11.544, 12.451, 13.766, and 15.517 $\mathrm{kW}$ of brake horsepower respectively, while at $2000 \mathrm{rpm}, \mathrm{B} 40$ produced $14.788 \mathrm{~kW}$ of brake horsepower. PD produced $10.325 \mathrm{~kW}$ of brake horsepower at $1600 \mathrm{rpm}$. From these results, we can deduce that CFB blends perform similarly to PD [52, 53].

Figure 5 shows the engine power output of various CFB blends and PD at brake load of $120 \mathrm{~N}$ and three-quarter throttle position. The engine power output decreased with the increase of percentage of CFB blend. Comparing between B10 and PD, there was a small percentage of reduction observed in engine power output which is $1.79 \%$. The percentage of reduction in engine power output for B20, B30, B40, and B50 were 2.27, $3.57,5.60$ and $7.43 \%$, respectively. From the above-stated percentage of reduction, it was analysed that reduction in engine power output did not vary much by using the CFB blends. The lower calorific value of the CFB was the main reason for the reduction of engine power output as compared to petroleum diesel [47]. Buyukkaya et al. reported power reduction with a lower heating value of biodiesel [54].

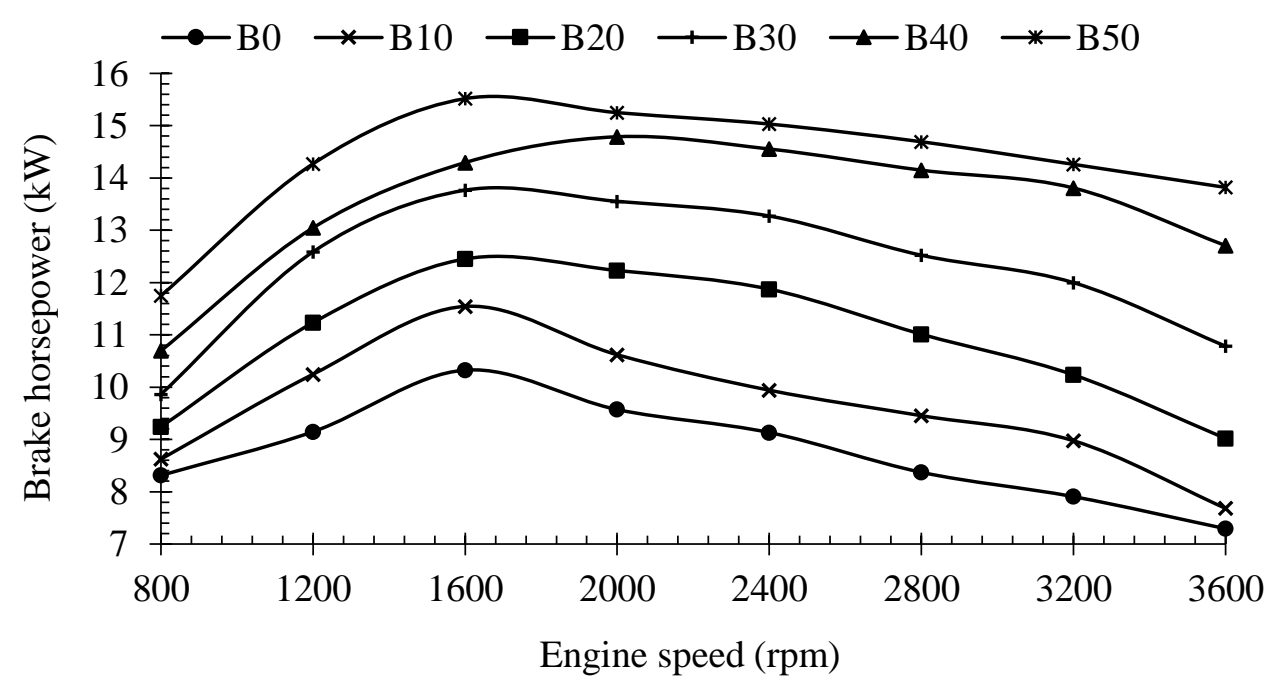

Figure 4. Brake horsepower of various biodiesel blends over variable engine speed. 


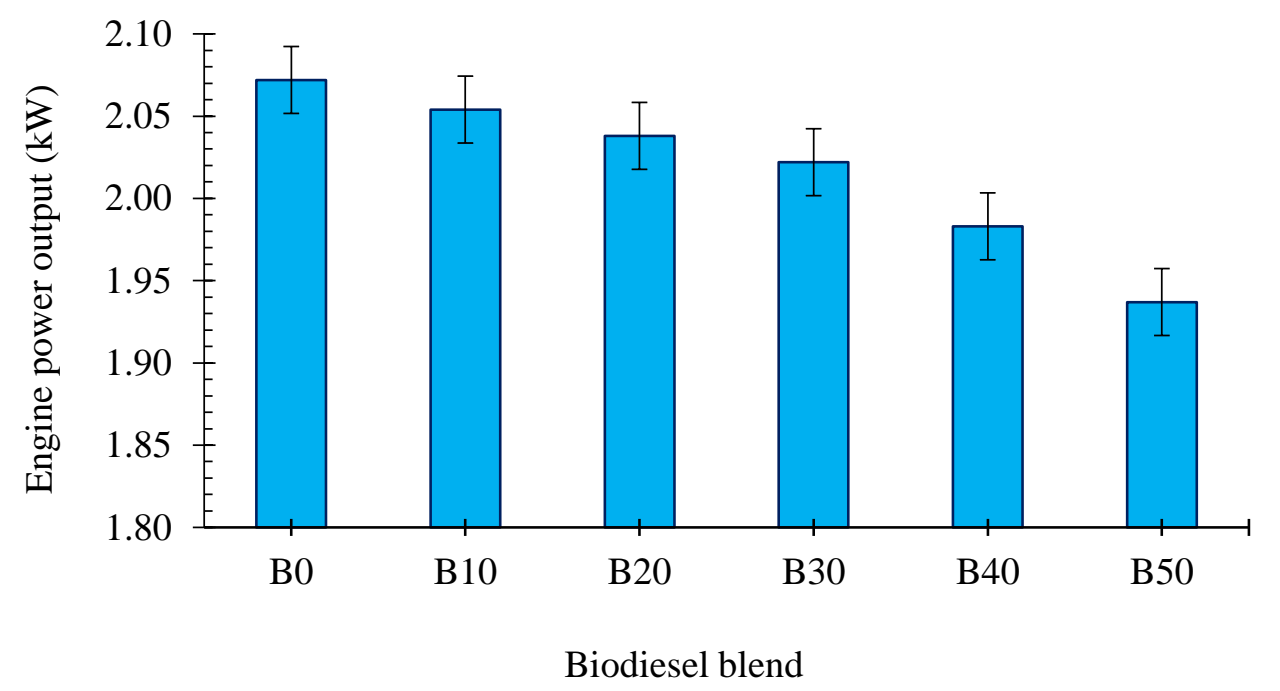

Figure 5. Engine power output of various biodiesel blends at $1600 \mathrm{rpm}$.

Figure 6 shows the specific fuel consumption (SFC) of PD and CFB blends at $1600 \mathrm{rpm}$, brake load of $120 \mathrm{~N}$ and three-quarter throttle position. The SFC of B10, B20, B30, B40 and B50 were 9.726, 9.802, 9.896, 10.024 and $10.245 \mathrm{~mL} / \mathrm{kW}$, respectively. The SFC of CFB blends increased when the biodiesel percentage increased in the blend. Comparing the SFC of CFB blends with PD; B10, B20, B30, B40 and B50 at 0.76, 1.54, $2.52,3.84$ and $6.13 \%$ respectively, they are all higher than B0. It was found that the increment in SFC became significant when a higher percentage of CFB was used for blending. This is due to lower heating value and higher density of CFB compared to PD $[23,51,53]$.

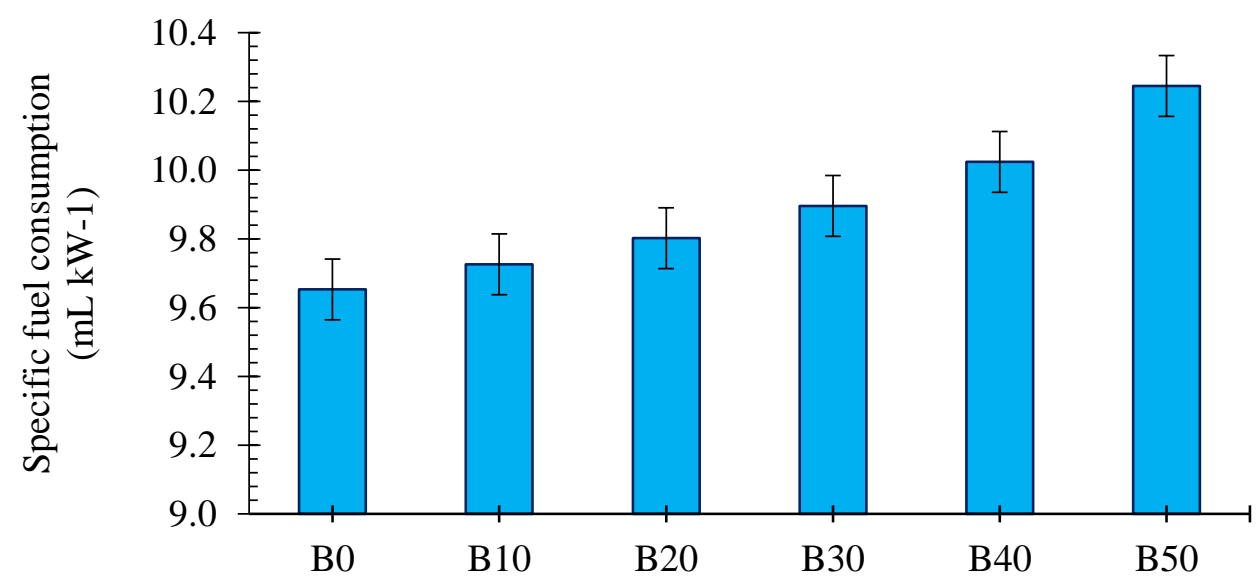

Biodiesel blend

Figure 6. Specific fuel consumption of various biodiesel blends at $1600 \mathrm{rpm}$.

\section{CONCLUSION}

This research successfully explored the possibility of using waste chicken fat as a potential feedstock for production of biodiesel. The physico-chemical properties and fatty 
acid composition of CFB were analysed. The chemical structure of CFB was investigated through GC and FT-IR techniques. A CFB yield of $96 \%$ was noted during $\mathrm{KOH}$ catalysed transesterification of chicken fat. The optimum reaction parameters were 1:4 of oil-tomethanol volume ratio and 0.5 wt. $\%$ of $\mathrm{KOH}$ catalyst concentration for reaction temperature of $60{ }^{\circ} \mathrm{C}$ and reaction time of $60 \mathrm{~min}$. The FT-IR analysis of chicken fat and CFB confirmed the conversion of chicken fat into CFB free from water and excess alcohol. The biodiesel fuel properties achieved were in compliance with EN 14214 biodiesel standards. The calorific value, viscosity, and acid value of CFB were lower than petrodiesel. The diesel engine performance test showed CFB blends outperform or performed similar to petrodiesel.

\section{ACKNOWLEDGEMENT}

The authors thank the Faculty of Engineering, UNIMAS and all staff members for providing research facilities, financial support under the grant F02/SpFRGS/1538/2017 and for their continuous support during this research.

\section{REFERENCES}

[1] Abas N, Kalair A, Khan N. Review of fossil fuels and future energy technologies. Futures. 2015;69:31--49.

[2] Hu B, Guild C, Suib SL. Thermal, electrochemical, and photochemical conversion of CO2 to fuels and value-added products. Journal of CO2 Utilization. 2013;1:18-27 .

[3] Halbouty MT. Giant Oil and Gas Fields of the Decade, 1990-1999. illustrate ed: American Association of Petroleum Geologists 2003; 2003.

[4] Shafiee S, Topal E. When will fossil fuel reserves be diminished? Energy Policy. 2009;37:189.

[5] Caliskan H. Environmental and enviroeconomic researches on diesel engines with diesel and biodiesel fuels. Journal of Cleaner Production. 2017;154:125--9.

[6] Shah SH, Raja Iftikhar A, Rizwan M, Rashid N, Mahmood Q, Shah Fayyaz A, et al. Potential of microalgal biodiesel production and its sustainability perspectives in Pakistan. Renewable and Sustainable Energy Reviews. 2018;81:76--92.

[7] Weekly All Countries Spot Price FOB Weighted by Etimated Export Volume. Washington DC: Office of Integrated Analysis and Forecasting, US Department of Energy; 2010.

[8] Ismail S, Abu SA, Rezaur R, Sinin H. Biodiesel Production from Castor Oil and Its Application in Diesel Engine. Journal on Science and Technology for Development. 2014;31:91--101.

[9] Rahman M, Rasul M, Hassan N. Study on the Tribological Characteristics of Australian Native First Generation and Second Generation Biodiesel Fuel. Energies. 2017:10.

[10] Doshi TK, Sebastian DSN, Bin ZN, Belinda S, Rachel W, Tim O, et al. Regulatory Reform - Case Studies on Green Investments. Asia-Pacific Economic Cooperation; 2013. p. 246.

[11] Saleh AA, Islam MS, Hamdan S, Maleque MA. Biodiesel Production from Crude Jatropha Oil using a Highly Active Heterogeneous Nanocatalyst by Optimizing Transesterification Reaction Parameters. Energy and Fuels. 2016;30:334--43. 
[12] Sharma YC, Singh B. Development of Biodiesel: Current Scenario. Renewable and Sustainable Energy Reviews. 2009:1646-51.

[13] Rehan M, Gardy J, Demirbas A, Rashid U, Budzianowski WM, Pant D, et al. Waste to biodiesel: A preliminary assessment for Saudi Arabia. Bioresource Technology. 2018;250:17--25.

[14] Jones C. Atmospheric Pollution. 1 ed: bookboon.com; 2008.

[15] Zhou A, Thomson E. The Development of Biofuels in Asia. Applied Energy. 2009;1:11-20.

[16] Mazaheri H, Chyuan OH, H. MH, Zeynab A, D. HM, Chin-TsanWang, et al. Rice bran oil based biodiesel production using calcium oxide catalyst derived from Chicoreus brunneus shell. Energy. 2018;144:10--9.

[17] Boey P-L, Pragas MG, Abd HS. Performance of calcium oxide as a heterogeneous catalyst in biodiesel production: A review. Chemical Engineering Journal. 2011;168:15--22.

[18] Reports A. CPO prices to see mid-to-long-term weakness. The Star Online. Kuala Lumpur2018.

[19] Canakci M. Combustion characteristics of a turbocharged DI compression ignition engine fueled with petroleum diesel fuels and biodiesel. Bioresource Technology. 2007;98:75.

[20] Baskar G, Aberna Ebenezer Selvakumari I, Aiswarya R. Biodiesel production from castor oil using heterogeneous $\mathrm{Ni}$ doped $\mathrm{ZnO}$ nanocatalyst. Bioresource Technology. 2018;250:793--8.

[21] Hoque ME, Singh A, Yong LC. Biodiesel from Low Cost Feedstocks: The Effects of Process Parameters on the Biodiesel Yield. Biomass and Bioenergy. 2011:1582-7.

[22] Mofijur M, Rasul M, Hassan N, Masjuki H, Kalam M, Mahmudul H. Assessment of physical, chemical and tribological properties of different biodiesel fuel. In: Rasul M, editor. Clean Energy for Sustainable Development. Amsterdam, the Netherlands: Elsevier; 2016. p. 441-61.

[23] Emiroğlu AO, Keskin A, Şen M. Experimental investigation of the effects of turkey rendering fat biodiesel on combustion, performance and exhaust emissions of a diesel engine. Fuel. 2018;216:266--73.

[24] Reddy ANR, Saleh AA, Islam MS, Hamdan S. Optimization of transesterification parameters for optimal biodiesel yield from crude jatropha oil using a newly synthesized seashell catalyst. Journal of Engineering Science and Technology. 2017;12:2723--32.

[25] Sakthivel R, Ramesh K, Purnachandran R. A review on the properties, performance and emission aspects of the third generation biodiesels. Renewable and Sustainable Energy Reviews. 2018;82:2970--92.

[26] M Sharif Hossain AB, Amru Nasrulhaq B, Ahmed AS, A. Majid HM, Chandran S, Zuliana R. Biodiesel Production from Different Used Vegetable Cooking Oil as Environmental Recycling Process and Economic Source - A Review. Proceeding of Encon 2007, 1st Engineering Conference on Energy and Environment2007.

[27] Piker A, Betina T, Nina P, Aharon G. A green and low-cost room temperature biodiesel production method from waste oil using egg shells as catalyst. Fuel. 2016;182:34--41.

[28] Vasudevan PT, Michael B. Biodiesel Production - Current State of the Art and Challenges. Journal of Industrial Microbiology and Biotechnology. 2008:421-30. 
[29] Sheedlo M. A review of the processes of biodiesel production. Basic Biotechnology 2008;4:61-5. 2008;4:5.

[30] Mansir N, Hwa TS, Umer R, Izham SM, Ping TY, Abdulkareem AG, et al. Modified waste egg shell derived bifunctional catalyst for biodiesel production from high FFA waste cooking oil. A review. Renewable and Sustainable Energy Reviews. 2018;82:3645--55.

[31] Guru M, Artukoglu BD, Keskin A, Koca A. Biodiesel production from waste animal fat and improvement of its characteristics by synthesized nickel and magnesium additive. Energy Convers Manage. 2009;50:502.

[32] Kirubakaran M, Arul Mozhi Selvan V. A comprehensive review of low cost biodiesel production from waste chicken fat. 2018. p. 390--401.

[33] Anr R, Saleh AA, Islam MDS, Hamdan S. Methanolysis of Crude Jatropha Oil using Heterogeneous Catalyst from the seashells and Egggshells as Green Biodiesel. Asean Journal on Science and Technology for Development. 2015;32:16--30.

[34] Sander A, Antonije Košćak M, Kosir D, Milosavljević N, Parlov Vuković J, Magić L. The influence of animal fat type and purification conditions on biodiesel quality. Renewable Energy. 2018;118:752--60.

[35] Saleh AA, Islam MS, Hamdan S. Active Heterogeneous CaO Catalyst Synthesis from Anadara granosa (Kerang) Seashells for Jatropha Biodiesel Production. MATEC Web of Conferences. 2017;87:02008.

[36] Reddy ANR, Saleh AA, Islam MS, Hamdan S. Active Razor Shell CaO Catalyst Synthesis for Jatropha Methyl Ester Production via Optimized Two-Step Transesterification. Journal of Chemistry. 2017;2017.

[37] Reddy ANR, Saleh AA, Islam MS, Hamdan S, Rahman MR, Masjuki HH. Experimental evaluation of fatty acid composition influence on Jatropha biodiesel physicochemical properties. Journal of Renewable and Sustainable Energy. 2018; 10:013103.

[38] Murugesan A, Umarani C, Chinnusamy TR, Krishnan M, Subramanian R, Neduzchezhain N. Production and analysis of bio-dieselfrom non-edible oils-A review. Renew and Sustain Energy Rev. 2009;13:34.

[39] Roschat W, Theeranun S, Boonyawan Y, Vinich P. Rice husk-derived sodium silicate as a highly efficient and low-cost basic heterogeneous catalyst for biodiesel production. Energy Conversion and Management. 2016;119:453--62.

[40] Korkut I, Mahmut B. Selection of catalyst and reaction conditions for ultrasound assisted biodiesel production from canola oil. Renewable Energy. 2018;116:543-51 .

[41] Harreh D, Saleh AA, Reddy ANR, Hamdan S. An Experimental Investigation of Karanja Biodiesel Production in Sarawak , Malaysia. Journal of Engineering. 2018:9.

[42] Abdullah, Rahmawati Sianipar RN, Ariyani D, Nata IF. Conversion of palm oil sludge to biodiesel using alum and $\mathrm{KOH}$ as catalysts. Sustainable Environment Research. 2017;27:291--5.

[43] Hanafi SA, Elmelawy MS, Shalaby NH, El-Syed HA, Eshaq G, Mostafa MS. Hydrocracking of waste chicken fat as a cost effective feedstock for renewable fuel production: A kinetic study. Egyptian Journal of Petroleum. 2016;25:531--7.

[44] O'Connor RT, Dupre EF, Feuge RO. The Infrared Spectra of Mono-, Di-, and Triglycerides. Journal of American Oil Chemistry’s Society. 1955;32:88-93. 
[45] Islam S, Saleh AA, Aminul I, Abdul AS, Chyi XL, Moniruzzaman M. Study on Emission and Performance of Diesel Engine Using Castor Biodiesel. Journal of Chemistry. 2014;2014:1--8.

[46] Hernández-Cruz MC, Meza-Gordillo R, Torrestiana-Sánchez B, RosalesQuintero A, Ventura-Canseco LMC, Castañón-Gonzáles JH. Chicken fat and biodiesel viscosity modification with additives for the formulation of biolubricants. Fuel. 2016:42-8.

[47] Mahmudul HM, Hagos FY, Mamat R, Adam AA, Ishak WFW, Alenezi R. Production, characterization and performance of biodiesel as an alternative fuel in diesel engines - A review. Renewable and Sustainable Energy Reviews. 2017;72:497--509.

[48] Saydut A, Sait E, Beycar KA, Canan K, Firat A, Candan H. Process optimization for production of biodiesel from hazelnut oil, sunflower oil and their hybrid feedstock. Fuel. 2016;183:512--7.

[49] Balat M. Potential alternatives to edible oils for biodiesel production - A review of current work. Energy Conversion and Management. 2011;52:1479--92.

[50] Khalid A, Jaat N, Sapit A, Razali A, Manshoor B, Zaman I. Performance and emissions characteristics of crude jatropha oil biodiesel blends in a diesel engine. International Journal Automotive Mechanical Engineering. 2015;11:57.

[51] Sundus F, Fazal MA, Masjuki HH. Tribology with biodiesel : A study on enhancing biodiesel stability and its fuel properties. Renewable and Sustainable Energy Reviews. 2017;70:399--412.

[52] Mat Yasin MH, Rizalman, Najafi G, Ali OM, Yusop AF, Ali MH. Potentials of palm oil as new feedstock oil for a global alternative fuel: A review. Renewable and Sustainable Energy Reviews. 2017;79:1034--49.

[53] Hasan MM, Rahman MM. Performance and emission characteristics of biodieseldiesel blend and environmental and economic impacts of biodiesel production: A review. Renewable and Sustainable Energy Reviews. 2017;74:938--48.

[54] Buyukkaya E. Effects of Biodiesel on a DI Diesel Engine Performance, Emission and Combustion Characteristic. Fuel. 2010;89:99-105. 